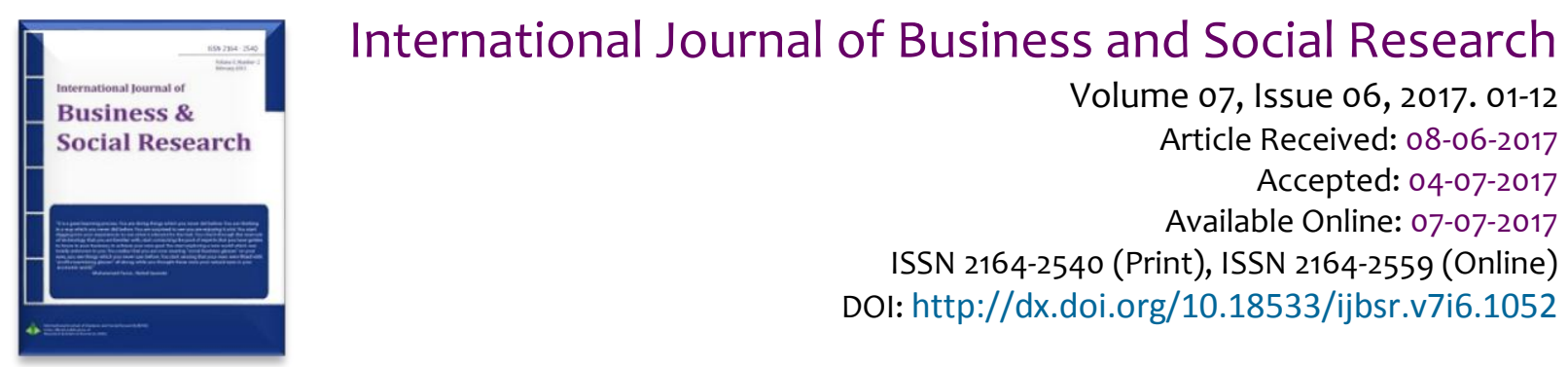

\title{
The Importance of Soft Skills in the University Academic Curriculum: The Perceptions of the Students in the New Society of Knowledge
}

\author{
Orlando Petiz Pereira', Carlos Alberto A.T. Costa²
}

\begin{abstract}
This study focuses on the notion of competence in a perspective of structural change. It addresses the academic curriculum and the soft skills essential for the holder of a Bachelor's Degree to adapt to the labour market and endow the citizen with instruments deemed necessary for the integration of the person in the different dimensions of life. Evidence unfolds a great deal of sensitivity on the part of students regarding soft skills. Nonetheless, there are substantial differences among courses and between genders. Data were collected through a questionnaire survey, which was applied to our bachelor students between October 2013 and January 2014. We resorted to the use of the analysis of the main components and we used the VARIMAX method for determining the variance, which is analysed by means of the ANOVA model. The study underpins the importance of autonomy and social and emotional skills in the student's global university education and highlights the sensitivity of the students to transversal competences -soft skills-, as required by the current labour market.
\end{abstract}

Keywords: Bologna declaration, higher education, labour market, skills.

JEL Codes: A23, I23, 125.

This is an open access article under Creative Commons Attribution 4.0 License, 2017.

\section{Introduction and objectives}

The Bologna Declaration underlines the importance of education and pedagogical co-operation in the development of stable societies and it considers that the quality of education should be focused on comparable criteria and methodologies. Yet, higher education has been mainly oriented toward learning processes based upon procedures that are aimed at the stability of the economic agent behaviour that, in turn, are geared to promoting excellence, both in performances as in the results. Hence, the cognitive abilities of each student are enhanced through a teaching model that differentiates the capacities, in a permanent search of "brains", adapted to such societal structure.

Although the Bologna Declaration proposes a pedagogical model which is more tailored to accommodate the needs of a knowledge-based society, one may perceive that the university education

\footnotetext{
${ }^{1}$ Department of Economics, Universidade do Minho, Portugal. E-mail: orlandop@eeg.uminho.pt

2 Universidade do Minho, Portugal.
} 
is still very much based on the transmission of knowledge. Indeed, the question is: are the players in the pedagogical process eager to change their attitude? In this work, our reflection focused upon the students' perceptions of the new practices as suggested by the Bologna Declaration and of what practices are actually implemented.

The discussion about what should be in education, with a special emphasis upon the superior, is old and roots itself a lot in the distinction of capabilities, which could be measured by means of performance revealed in several areas of knowledge. But, as it can be seen in daily practice, the Bologna Declaration:

on the one hand, seeks to standardise criteria for comparison based on rankings, which translates into a perspective that highlights the idea of a teaching model oriented toward competitive differentiation in line with traditional models of teaching and learning, some of which are still rather dominant.

(ii) On the other hand, it emphasises the principle of permanent construction of learning structures with a greater connection amongst its various dimensions. It also ponders flexibility, which strengthens the idea of a learning process that accommodates itself to the rhythm of each individual, whilst placing the person at the centre of his own learning process.

Whilst internalising the "competitiveness" feature in higher education, the Bologna Declaration seems to be geared toward the strengthening of its end result, whilst quantifying and hierarchising through the construction of rankings. In this manner, it assumes that the criteria for such output are stable, immutable, objective and comparable. On the other hand, when it admits (i) flexibility in the learning model and (ii) mainstreaming the skills in the individual and autonomous search for excellence, it also allows for responsible freedom toward success. This perspective differs from the still dominant teaching processes, which are based on a market structure where competitiveness is sustained in the differentiation and in rigid models of performance assessment. In this light, in a knowledge-based economy one advocates that competence involves a combination of knowledge, skills and attitudes and that education should promote diversified skills, which is contrary to the traditional knowledge-based model. In this context, cultural competence outshines as a determining factor of personal and professional success (Chen, 2016).

Having in mind the aforementioned scenario, this study reflects on the notions of qualification and competence, in a perspective of structural change. It is worth mentioning we have revisited some production models of competence to counteract the dominant results-oriented process to the dynamic process that aims at adapting itself to change. We envision to contribute to a critical reflection on the construction process of active learning for endowing students with the tools deemed necessary for their integration in the different dimensions of their lives.

To this end, Section two addresses the academic curriculum and its relationship to the soft skills while Section three sheds light upon the methodology, the sample and the results obtained, which precedes the discussion of the main conclusions and references.

Data were collected through a questionnaire survey answered by students pursuing Law, Integrated Master in Engineering and Information Systems Management (MIEGSI), International Business (NI) and Applied Statistics (EA) Bachelors - as taught at the University of Minho - as well as Engineering Bachelors - as offered at the Polytechnic Institute of Porto (ISEP), between October 2013 and January 2014.

This study mirrors the work of some authors on the academic curriculum and soft skills which accommodate and comply with the Bologna Declaration objectives. Then we present our empirical study, with the methodological design of the study, and analysis of the main results. Finally, we discuss the results and its relationship with the theoretical assumptions concerning the academic curriculum and soft skills. We conclude with the main aspects highlighted by the research. 


\section{Academic curriculum and soft skills}

Due to the new economic order, marked by an informational evolutionary revolution, much has been discussed about the qualifications and skills hold by employees (Civelli, 1997; Fleury \& Fleury, 2001; Laužackas, Tūtlys \& Spūdyte, 2009; Pereira, 2013a; Pereira, 2013b; Pereira, 2015). The education and training agenda has also unveiled much concern, thereby questioning academic curricula (Athey \& Orth, 1999; Binks, 1996; European Commission, 1995; Fallows \& Steven, 2000; Garavan, Morley, Gunnigle \& Collins, 2001; Hawkins \& Winte, 1996; Laughton \& Montanheiro, 1996; Stagg, 1996; Waterman, Waterman \& Collard, 1994). Hence, the Bologna Declaration also calls for people's awareness in order to expedite academic curricula, which should be accommodated to the current economic and social reality, given the various societal shocks we have been witnessing over the past three decades. Such societal shocks imply demand for self-reliance skills. The undergraduate degree holder should master these skills. And yet, students should also be able to master new skills because they are players in the labour market (Chen, 2016; Hawkins \& Winter, 1996). Therefore, they should be endowed with "meetings skills, negotiation skills and networking Skills" (Hawkins \& Winter, 1996, p. 5). These should be linked and thus bridge other generalist oriented skills, as it is the case of the market knowledge, management skills and the use of information technologies. As a last element, and as stated by the above authors, there is knowledge and skills in specific areas, the specialist skill, which render the person an expert in something related to a disciplinary area of the course or a niche of the market to be developed.

The perspective defended by Hawkins and Winter (1996) is supported by Stagg (1996, p. 11) who says an academic curriculum should be broad, comprehensive and balanced in order to "prepare pupils for the opportunities, responsibilities and experiences of adult life". He also argues that the curriculum should promote the students' spiritual, moral, cultural, mental and physical enhancement. In this context, education should prepare students to identify opportunities and to assume responsibilities and live experiences throughout their lives. These are differentiating characteristics of graduate holders. They steer their entrepreneurial skills and drive for professional performances of excellence. These features render individuals ever more responsible, tolerant, cooperative and socialising. These are the characteristics of a new paradigm, potentially alternative to the dominant paradigm, the status quo, because the latter one has given great signs of inability to guide the population toward a welfare economic model, whilst endeavouring to reduce the emergence of societal biases. In fact, in a holistic perspective, the underlying cultural component to a curriculum is a form of personal development and human capital within organisations (Chen, 2016; Pereira, 2013a; Tejada, 2012). Therefore, students should be driven and eager to acquire new skills to achieve self-efficacy, and respond to pluralism and social inclusion (Ibáñez-Martín, Fuentes \& Barrio, 2012; Tejada \& Ruiz, 2016). Hence, curricula are a pool of cultural competences which allow people to interact with different economic, social, cultural and emotional backgrounds and inspires respect for diferences, so believe Badia and Becerril (2016) and Chen (2016).

In the 90's, Twentieth Century, the BTEC (Business and Technology Education Council) discussed at length educational vocation, as well as the programme of new qualifications and skills training (Laughton \& Montanheiro, 1996). These talks outshine some concern to establish a relation between the education system with the labour market and the need for a competent performance in the workplace. The political position as assumed by BTEC has highlighted the importance of learning by doing, where informal learning is important in the individual and society intellectualisation process. In this manner, it can be stated that the tutor's role is that of a learning facilitator and the students could learn much better upon receiving feedback from their tutors (Hoffmann, 1999). The importance of the role played by the tutor in the professional success is underlined by Zhou (2014) and Munthe, Malmo \& Rogne (2011). Zhou (2014) states that, from the second half of the 2oth century onwards, throughout countries, there can be pinpointed strong social and economic changes, which impacted directly on the education system. He considers that curricular reforms are fundamental to economic and social reforms, because handling everyday problems, be open-minded, creative and comprehensive and resort to the application of collaborative learning principles, is the outcome of educational systems adapted to a competitive market and a strong knowledge-based economy. Smidt (2015) does also consider that there is a close relationship 
between the academic success and professional competence. This is the line of thought in which Thongthew (2014) asserts that the education systems call for changes to better prepare individuals for the expected changes of society. Therefore, the curricula must endow students with diverse skills and critical thinking to adapt to the new technological age because knowledge complexity requireseducation systems to get involved in soft skills (Martins, Martins \& Pereira, 2013). These foster productivity and personal professional, social and organisational development (Pereira, 2015), and yet the current era of knowledge lives on continuous, formal, non-formal and informal learning (Pereira \& Assoreira, 2012; Pereira \& Coutinho, 2009; Pereira \& Correira, 2007).

Thanks to the BTEC, attention was drawn to the need for the academic curriculum to enhance Skills. It defends that it should embody various common Skills. In 1991, it recommended the introduction of a more sophisticated strategy for the production of common competencies, whilst stating that education centres in The United Kingdom should adopt and prescribe the following seven common skills (Laughton \& Montanheiro, 1996, p. 19): (i) managing and developing self; (ii) working with and relating to others; (iii) communicating, (iv) managing tasks and solving problems; (v) applying numeracy, (vi) applying technology, (vii) applying design and (vii) creativity.

As for the aforementioned seven skills, the authors did a survey by applying a questionnaire to graduates. The main question was: "Considering your previous education, especially the BTEC course you have completed, how did it contribute to your professional/business position or any further academic study you are now realising? (Laughton \& Montanheiro, 1996). The results are enlightening because about 50\% of respondents say that their training prior to their bachelor degree had been important or very important. The other part says that the bachelor degree was not decisive or had little contribution.

Another question sought to ascertain the importance of soft skills as opposed to hard skills: "Rank the importance of the common skills to you nowadays by indicating the usefulness of these skills to your employment, work or academic situation on a scale ranging from 10 (very much) to 1 (very little)", as shown in the Table 1.

Table 1: Importance of soft skills

\begin{tabular}{lrr}
\hline Common skill & Mean average & Standard deviation \\
\hline Managing and developing self & 7.72 & 2.14 \\
Working with others & 7.83 & 1.83 \\
Communicating & 8.21 & 1.83 \\
Managing tasks/solving problems & 7.61 & 2.23 \\
Applying numeracy & 5.21 & 2.46 \\
Applying technology & 5.75 & 2.27 \\
Applying design & 4.93 & 2.56 \\
\hline
\end{tabular}

Source: Laughton and Montanheiro (1996, p. 22).

It is interesting to look at the evidence. Indeed, the soft skills do play a very important role if we compare to hard skills. Regarding soft skills, we would highlight the fact that the respondents are convinced of their importance. Indeed, the mean value of responses is equal to or greater than 7.61 , on a scale of one to ten. This is validated by the Blanco, Jové and Reverte (2012), Ibáñez-Martín, Fuentes and Barrio (2012), Pereira (2015) and Roing Cotada and Villarreal Rodríguez (2008), where the transferable skills are ever more valued by students and civil society and they are also much sought after and valued by companies.

Nevertheless, the BTEC does also draw our attention to all those operating in the labour market. On the assumption that workers learn through practice, whose informal learning cannot be ignored, BTEC does defend the need to validate their competencies. This idea is also supported by Civelli (1997, p. 226) when he says "people learn not only inside the boundaries of "institutions", but in everyday life situations". However, higher education models have been insisting on the importance of core skills (Binks, 1996). Nonetheless, this author considers that there seems to be a greater awareness of the shortage of people holding transferable skills, contrary to what happens with an academic background. Although one 
cannot neglect the value of academic skills, there is an increase in demand for graduates holding personal skills. In this light, flexibility is becoming a prerequisite for the labour market, which rests upon soft skills, contrary to the valuation of hard skills, a feature which was highly valued until very recently (Binks, 1996). In fact, valuing motivation of human capital in organisations, streamlines the development of competencies (Athey \& Orth, 1999), whose capital has key features to the flexibility and adaptability (Garavan, Morley, Gunnigle \& Collins, 2001; Waterman, Waterman \& Collard, 1994), which is strategic in the current informational revolution.

\section{Empirical analysis}

\subsection{Sample and methodology}

Our empirical study focus on the construction and implementation of a questionnaire called "Importance of Transversal Competencies in Higher Education". It aims at collecting and analysing higher education students opinion about the importance of soft skills training in their curriculum.

The questionnaire was implemented throughout the first semester of the school year of 2013/14, between October 2013 and January 2014, in some undergraduate degree programmes at the University of Minho, henceforth referred to as UMinho and the Polytechnic Institute of Porto, hereinafter referred to as ISEP. The questionnaire has been constructed according to a Likert scale with five response possibilities, where the value one (1) corresponds to "completely agree and the value five (5) to" completely disagree ". The value six (6), residually collects opinions to the type of reply "don't know/no answer". Thus, the lower is the average value of the variable, the higher the agreement of the respondent and vice versa.

The respondents were first-year bachelor students. We aimed at perceiving their perception about their experience at University. The questionnaire allowed for the collection of 424 responses $(n=424)$, of which $48 \%$ of the Instituto Superior de Engenharia do Porto (ISEP) and $52 \%$ of the University of Minho. The ISEP respondents are students pursuing Engineering courses and the respondents from University are thus divided: $16 \%$ attending the Law School (Law, full-time students); $15 \%$ attending Integrated Master in Engineering and Information Systems Management (MIEGSI, full-time students); 09\% Integrated Master in Engineering and Information Systems Management (MIEGSI, post-labour students); 07\% attending International Business ( $\mathrm{NI}$, post-labour students) and 05\% attending Applied Statistics (EA, fulltime students).

It is interesting to underline that $75 \%$ of respondents are male. By age level, respondents split as follows: $76 \%$ are less than 20 years; $17 \%$ fall in the interval between 20 and 25 years old and $07 \%$ are over 25 years old. It is also interesting to pinpoint the fact that $89 \%$ of students are full-time students whereas the remaining $11 \%$ are part-time students attending post-labour programmes.

The analysis was supported by the construction of five constructs corresponding to various transversal training vectors: (i) training for autonomy; (ii) training for communication; (iii) training for socioemotional responsibility and $(\mathrm{v})$ specific training with transversal importance resorting to the following questions of the questionnaire:
a) develop my skills for life
b) develop, essentially, my technical skills
c) Develop my social skills
d) Develop my emotional skills
e) valuing my autonomy
f) develop my versatility to face different and adverse situations
g) valuing oral communication skills
h) valuing written communication skills
i) develop my relational/interpersonal skills
j) instil the necessity of seeking alternative solutions to problems 
k) develop my autonomy to make decisions in uncertain situations

l) enhance the spirit of entrepreneurial initiative

m) stimulate my creative skills

n) provide me with basic knowledge for the exercise of a profession

o) concern me essentially with the specific skills of the course

p) promote oral and written skills

Afterwards, we performed a factor analysis in order to analyse the consistency of constructs and make any corrections. We have done a Principal Component Analysis and we have used the VARIMAX method with rotation of components for controlling for the variance. We have initially determined five components that drew $72 \%$ of the variance and, given the results, it seemed more appropriate to build just 4 components (QE-Autonomy; QF-Communication; QG-Socio-emotional Responsibility; QH-Specific Training), which drew $69 \%$ of total variance, being (i) $33,6 \%$ the first component (QE), (ii) $18 \%$ the second component (QF), (iii) 11\% the third component (QG) and (iv) $6 \%$ the fourth component (QH), as displayed in Table 2.

Table 2: Construction of four main constructs

\begin{tabular}{|c|c|c|c|}
\hline $\begin{array}{l}\text { Component } 1 \\
\text { Autonomy } \\
\text { (QE) } \\
\text { (Var 33.6\%) }\end{array}$ & $\begin{array}{l}\text { Component } 2 \\
\text { Communication } \\
\text { (QF) } \\
(\text { Var } 18 \%)\end{array}$ & $\begin{array}{l}\text { Component } 3- \\
\text { Socio-emotional } \\
\text { Responsibility (QG) } \\
(\text { Var } 14.1 \%)\end{array}$ & $\begin{array}{l}\text { Component } 4- \\
\text { Specific Training } \\
\text { (QH) } \\
\text { (Var 6\%) }\end{array}$ \\
\hline $\begin{array}{l}\text { a) develop my skills for life } \\
\text { e) valuing my autonomy } \\
\text { f) develop my versatility to face } \\
\text { different and adverse situations } \\
\text { j) instil the necessity of seeking after } \\
\text { alternative solutions to problems } \\
\text { k) develop my autonomy to make } \\
\text { decisions in uncertain situations. } \\
\text { I) enhance the spirit of entrepreneurial } \\
\text { initiative } \\
\text { m) stimulate my creative skills } \\
\text { n) provide myself with basic knowledge } \\
\text { for the exercise of a profession }\end{array}$ & $\begin{array}{l}\text { g) valuing oral } \\
\text { communicati } \\
\text { on skills. } \\
\text { h) valuing } \\
\text { written } \\
\text { communicati } \\
\text { on skills. } \\
\text { p) Promote oral } \\
\text { and written } \\
\text { skills }\end{array}$ & $\begin{array}{l}\text { c) Develop my social } \\
\text { skills } \\
\text { d) Develop my } \\
\text { emotional skills } \\
\text { i) develop my } \\
\text { relational/interpe } \\
\text { rsonal skills }\end{array}$ & $\begin{array}{l}\text { b) develop, } \\
\text { essentially, my } \\
\text { technical } \\
\text { skills. } \\
\text { o) concern myself } \\
\text { essentially } \\
\text { with the } \\
\text { specific skills } \\
\text { of the course }\end{array}$ \\
\hline
\end{tabular}

Hence, considering the above four constructs, we have undergone a correlational analysis amongst the four constructs. Then, we have determined which of the items had greater importance within each construct and, finally, we have analysed the variance whilst resorting to the ANOVA model of SPSS, by courses, gender and full-time/part-time student status.

\subsection{Analysis of results}

Variables considered "more" and "less" important by students in training. The variables that have obtained a score of major importance in the training were (see table 3 ):

Table 3: Variables considered more important

\begin{tabular}{lcr}
\hline Question / variable & Average & $\begin{array}{r}\text { Standard } \\
\text { deviation }\end{array}$ \\
\hline n) provide myself with basic knowledge for the exercise of a & 1.71 & 1.18 \\
$\quad$ profession & & 1.72 \\
a) develop my skills for life & 1.75 & 1.08 \\
j) instil the necessity of seeking after alternative solutions to problems & 1.19
\end{tabular}


b) develop, essentially, my technical skills

The variables that have scored "less" in terms of importance in the training were (see table 4):

Table 4: Variables scored less

\begin{tabular}{lrr}
\hline Question / variable & Average & $\begin{array}{r}\text { Standard } \\
\text { deviation }\end{array}$ \\
\hline d) develop my emotional skills & 3.03 & 1.24 \\
o) concern myself essentially with the specific skills of the course & 2.57 & 1.54 \\
i) develop my relational/interpersonal skills & 2.40 & 1.24 \\
\hline
\end{tabular}

Source: Own Elaboration

The correlations amongst the four constructs are statistically significant and with intensity fluctuating between the average and the high. We thus highlight (i) Autonomy (QE) and Communication ( $\mathrm{F}$ ): $\mathrm{r}=0.72$, $p<.001$ and (ii) Socio-emotional Responsibility and Communication: $r=0.54, p<.001$. On the other hand, we highlight poor correlations in the constructs: (i) Socio-emotional Responsibility (QG) and Specific Training (QH): $r=0.26, p<.001$ and (ii) Communication (QF) and Specific Training (QH): $r=0.34, p<.001$.

\subsection{Anovas model}

\section{A. Distinction by gender}

At first, we controlled for the homogeneity of variances through the Levine Test, from which one may assume the homogeneity of variances in all constructs, as shown in Table 5:

Table 5: Test $\mathrm{f}$ homogeneity of variances

\begin{tabular}{lrrrr}
\hline & Levene Statistic & $\mathrm{df} 1$ & $\mathrm{df2}$ & Sig. \\
\hline QE & .645 & 1 & 421 & .422 \\
QF & .009 & 1 & 422 & .923 \\
QG & 3.463 & 1 & 421 & .063 \\
QH & .881 & 1 & 422 & .348 \\
\hline
\end{tabular}

Source: Own Elaboration

We found differences by gender in communication (QF) and socio-emotional responsibility (QG). The Communication construct (QF) is considered as an important one by female students as opposed to male students: $F(1,422)=10.51, p=.001$, average difference $=0.35$, $s d=0.11, M($ female $)=1.86$, sd=0.99.

Again, regarding socio-emotional responsibility $(\mathrm{QG})$ is more valued by female students than by male students: $F(1.421)=7.5, p=.05$, average difference $=0.29$, $s d=0.07, M($ female $)=2.32$, $s d=0.88$.

\section{B. Distinction by degree programmes}

Similarly, at first, we controlled for the homogeneity of variances by means of the Levine Test. One may assume that the homogeneity of variances in three constructs ( $\mathrm{QF}, \mathrm{QG}$ and $\mathrm{QH}$ ) and heterogeneity in the autonomy one (QE); as such we have resorted to the Games-Howell' Statistics:

Table 6: Test $\mathrm{f}$ homogeneity of variances

\begin{tabular}{lrrrr} 
& Levene & & & \\
& Statistic & $d f 1$ & $d f_{2}$ & Sig. \\
\hline QE & 4.520 & 5 & 417 & .001 \\
QF & 1.825 & 5 & 418 & .107 \\
QG & .912 & 5 & 417 & .473
\end{tabular}


We found statistically significant differences in the first three constructs and we did not observe only in the construct "Specific Training" (QH). As such:

\section{B1) Construct autonomy (QE)}

We only found significant statistical differences between the opinion as materialise by NI students (postlabour) and MIEGSI (post-labour). Interesting to highlight that NI students consider autonomy more important than MIEGSI students (post-labour): $F(5,417)=2.65, p=.02$, diference $($ NI-MIEGSI)=-.609, sd=.2, $\mathrm{p}=.05, \mathrm{M}(\mathrm{NI})=1.6, \mathrm{sd}=0.54$.

\section{B2) Construct communication (QF)}

There is evidence of significant statistical differences between the Law and the MIEGSI bachelor degree programmes (full-time) and those as offered by ISEP; and between the course of NI and MIEGSI programmes (post-labour) and those offered by ISEP.

We have also found an identical behaviour between the Law and International Bussiness (NI) courses, and both courses identify "Communication" with greater importance in their curricula. Full-time students attending MIEGSI courses have also attributed greater importance to this construct than post-labour students pursuing the same programmes.

$F(5,417)=4.77, p<.001$. Difference (Law-MIEGSI post-labour) $=-.85, \mathrm{sd}=.19, \mathrm{p}<.001 ; \mathrm{M}(\mathrm{MIGSI} \mathrm{PL})=2.65$, $\mathrm{sd}=1.19$.

Difference $($ Law-ISEP $)=-.4, \mathrm{sd}=.13, \mathrm{p}=.004 ; \mathrm{M}($ Law $)=1.79 \mathrm{sd}=1.06$.

Difference (NI-MIEGSI post-labour) $=-.85, \mathrm{sd}=.23, \mathrm{p}<.001 ; \mathrm{M}(\mathrm{NI})=1.8, \mathrm{sd}=0.88$.

Difference $(\mathrm{NI}$-ISEP) $=-.39, \mathrm{sd}=.19, \mathrm{p}=.004 ; \mathrm{M}(\mathrm{ISEP})=2.19, \mathrm{sd}=0.86$.

Difference (MIEGSI full-time-MIEGSI post-labour) =-.2, sd=.23, $\mathrm{p}=.005 ; \mathrm{M}(\mathrm{MIGSI}$, full time $)=2.09$, sd = 1.06 .

Difference $(E A-M I E G S I$, post-labour $)=-.49, \mathrm{sd}=.25, \mathrm{p}=.05 ; \mathrm{M}(\mathrm{EA})=2.16, \mathrm{sd}=0.87$.

ISEP students consider this item less importance and the assigned by all other courses. Differences are statistically significant, where this skill is more valued by the Law students and less by students pursuing the MIEGSI course (post-labour) as compared to those pursuing the MIEGSI course (full-time) and the Statistics course.

\section{B3) Construct socio-emotional responsibility (QG)}

One may only find significant statistical differences between the views of Law students and ISEP, where Law students appreciate more this construct, and between the MIEGSI (full-time) and those from ISEP, where first-year students value more this construct: $F(5,417)=2.16, p=0.05$; Difference (Law-ISEP) $=-.31$, $\mathrm{sd}=.13, \mathrm{p}=.02 ; \mathrm{M}(\mathrm{Law})=2.34, \mathrm{sd}=1.05$. Difference $($ MIEGSI Full-Time-ISEP $)=-.33, \mathrm{sd}=.14, \mathrm{p}=.02 ; \mathrm{M}(\mathrm{MIEGS}$ Full time $)=2.33, \mathrm{sd}=1.06$.

Insofar the Construct "Specific Training" $(\mathrm{QH})$ is concerned, there is no difference of opinion in none of the courses.

\section{Distinction by working-student}

We did not find significant statistical differences for any of the constructs. 


\section{Discussion}

Our study intends to stimulate a reflection on the qualities of an academic curriculum, in order to adapt it to a knowledge-intensive society. To do so, we have evaluated the students' perceptions on the importance of soft skills. The analysis unfolds into four main areas of reflection: (i) autonomy, (ii) communication, (iii) socio-emotional development, and (iv) specific training for the labour market.

Evidence show students appreciate more the variables of learning autonomy and less those related to the management of emotions. This feeling seems to tune up with the demands of a demanding labour market regarding commitment and responsibility. The importance assigned to autonomy by the students is consistent with the markets' perception and it is in line with those who argue that generic and transferable skills in the academic curriculum facilitate personal development and enhance performance (Chen, 2016; Ibáñez-Martín, Fuentes \& Barrio, 2012; Pereira, 2015; Tejada, 2012). According to Badia and Becerril (2016), Munthe, Malmo and Rogne (2011), Smidt (2015) and Thongthew (2014) the change of curricula is a pillar of economic reform and the change of society. It is therefore difficult to understand the very universities' slim steps toward change, due to the fact that interpersonal relationships are the basis of the functioning of organisations, where conflicts do frequently materialise and where it is important to know how to overcome them. therefore, it would be expected to value the management of emotions, as it is case regarding autonomy.

According to Goleman (1997), there are many paths to success in life, and many areas where other skills are rewarded. Emotional intelligence provides advantages in a complex society. In fact, and according to this author, it is important to understand the other, both in terms of motivation and work habits. According to Goleman (1997), cognition and emotion are not opposing skills. As for interpersonal relationships, social ineptitude would be a problem that could jeopardise success in a competitive world. Therefore, we have questioned ourselves about (i) the reasons for different valuations revealed by the students, (ii) how do students perceive the labour market and (iii) the required skills to accept change as well as their availability and agility to change.

The results by gender have unfolded that females appreciated more communication variables than the males. The very same happens in what concerns interpersonal relationships. Can we interpret these results only in the light of gender differences? Are females more sensitivity than males at the level of very same market requirements? One may also ask if the expectations are different depending on the gender. In this respect one might think if the job market, which has long been the place of rise of men, will it be contributing to degrees of adaptation distinguished by gender. But, will not this cultural longevity, such as underlined by Badia and Becerril (2016) and Chen (2016), have caused some stiffness and apathy regarding the sensitivity of men, which may call for an urgent inversion/change?

If we resort to an analysis by degree/course, one understands that transversal/soft skills were highly valued. And yet, there are statistically significant differences of greater appreciation on communication variables by Law and International Business students as opposed to Engineering students. If, for Law students, communication is an important professional tool, one can assume that the communication skills are part of their specific training. Regarding the perception their importance by the International Business students, such an attitude seems to us to be strategic in the construct of their pack of competencies, such as foreign languages, in a more globalised and complex world. Hence, we perceive opportunities for collaboration in jobs across borders, with the need for linguistic proficiency in various fields, along with others of intrapersonal and interpersonal character, which appeals to other competencies to support the techniques. So it is not surprising that such attitudes do materialise.

After all, we could ask: what components are most associated with the exercise of a profession and how to develop the skills, bearing in mind that the developer is a player in the labour market, requiring diverse skills (Hawkins \& Winter, 1996; Stagg, 1996)? And, should the academic curriculum address the performance of a specific function, or should it also be concerned with the development of the person thereby envisioning his/her social and labour insertion? 
Traditionally and culturally, students seem to enhance more technical skills, thereby appreciating others to a lesser degree. But, emotional management, despite being the least valued by students, is present in all the activities within organisations and throughout the student's academic career, helping him/her to maintain a high degree of academic satisfaction, by knowing to control for the most adverse moments and situation of their experience in the academia, the emotional intelligence in dealing with difficulties, inter alia. All these competencies should be in everyday life of a university student, in the light of what happens with a professional in an organisation, as recommended by Chen (2016), Laughton and Montanheiro (1996), Pereira (2015) and Tajada and Ruiz (2016). It is therefore of great importance to develop skills that are not visible directly on the individual, thus adapting him/her to a knowledge-based economy. If this does not happen with the required intensity and urgency, the University student will be a diminished professional in the labour market and a misfit in society. Therefore, the concern of the Bologna Reform focuses on the need for adaptation of the academic curriculum to adjust it to a society that has to tackle constant and permanent technological and societal shocks, which calls for changes in the type of skills that should be developed at the University.

\section{Conclusion}

This study addresses the importance of the teaching-learning process in higher education. It aims at deepening awareness about the multiplicative value soft/transversal skills play on the individual and organisational performance. In this respect, the available data for Portugal are poor in qualitative and quantitative terms. However, the available empirical analysis evidence sheds light upon:

(i) Students who are pursuing all courses under analysis, both at the University of Minho and at Polytechnic Institute of Porto, emphasised the importance of soft skills in their training/education. However, the importance attributed to each group of competencies is not equally perceived and pondered thereby unveiling differences either by course or by gender.

(ii) Students of Law and International Business value more the development of oral and written communication skills. Even when one compares to other skills, though with less intensity, students of International Business and Law seem to give greater importance than those pursuing the most technical courses such as MIEGSI and those attending ISEP's courses.

(iii) The Socio-Emotional Responsibility skills seem to be perceived as more important amongst female students and Law Programme which is consistent with their specific training / education.

(iv) In an increasingly competitive education model and based on the results, ability is often privileged in relation to effort and to work cooperatively in a team environment.

(v) It seems a paradox to base excellence upon ability and at the same time acknowledge the importance of effort and evolution in the teaching-learning process.

(vi) Transversal skills are more in line with the second vector of training than that based more upon competitiveness and result.

(vii) Teamwork will be a model of education development in cooperation in which the acquired competence goes far beyond the goal centred only on results.

With regard to the current work evidence, we could ask:

1. To what extent is the degree of structural change in the current teaching-learning system consistent with the guidelines of the Bologna Process?

2. Considering the insensitivity of data on transversal skills, is the current higher education system addressing the overall individual training whilst responding to the individual social integration?

3. Has the current education format been designed as a process to enhance emotional, relational, behavioural and cognitive intelligence of the individual?

4. Are the current academic curricula contributing to the integral development of the individual and stimulating the individual present and future professional performance?

These are some of the issues that beset us and to which the present work does not respond. However, we are convinced that, the knowledge-based economy, focusing on results-standard, as appanage in the 
dominant system, constraints creativity, enthusiasm and motivation of the individual, with negative external economies on individual, team and organisational performance. Therefore, we think that the issues we hereby raise must be addressed by different disciplinary areas, given their complementarity in the information society. Ultimately, this is a national issue, because it requires teaching guidelines tackling creativity, which is an intangible feature but that enshrines explanatory power regarding the national performance.

In the light of our results, we think it is important and urgent to devise a new policy for the governance of Universities. These should consider transversal competences -soft skills- and interdisciplinarity of utmost relevance. As a matter of fact, we propose the implementation of diverse pedagogical practices, focusing on interpersonal relationships, communication and personal development. To this endeavour, we believe that all stakeholders in the educational process must be committed to achieving these goals.

\section{References}

Athey, T. R., \& Orth, M. S. (1999). Emerging Competency Methods for the Future. Human Resource Management, 38(3), 215-228.

Badia, A., \& Becerril, L. (2016). Renaming teaching practice through teacher reflection using critical incidents on a virtual training course. Journal of Education for Teaching, 42(2), 224-238.

Binks M. (1996). “Enterprise in Higher Education and the graduate labour market". Education + Training, 38(2), 26-29.

Blanco, P., Jové, M. C., \& Reverter J. (2012). Paradigma estratégico para el desarrollo de habilidades competenciales. Estudio descriptivo sobre la variabilidad en la percepción de habilidades competenciales de 40 alumnos de educación física en fase de formación inicial. Educación XX1, 15(2), 231-248.

Chen, P. Y. (2016). Teaching in offshore programmes: an assessment of university faculty's self-efficacy, cultural competence and preparedness. Journal of Education for Teaching, 42(2), 188-204.

Civelli, F. F. (1997). New competences, new organizations in a developing world. Industrial and Commercial Training, 29(7), 226-229.

European Commission (1995). Teaching and Learning: Towards the Learning Society, available at http://www.cec.lu/en/comm(dg22/dg22.html, [accessed 23/10/11].

Fallows, S., \& Steven, C. (2000). Building employability skills into the higher education curriculum: a university-wide initiative. Education + Training, 42(2), 75-82.

Fleury, M. T. L., \& Fleury, A. (2001). Construindo o Conceito de Competência. Revista de Administração Contemporânea (RAC), Edição Especial, 183-196.

Garavan, T. N., Morley M., Gunnigle, P., \& Collins, E. (2001). Human capital accumulation: the role of human resource development. Journal of European Industrial Training, 25(2/3/4), 48- 68.

Goleman D. (1997). Inteligência Emocional. Temas e Debates, Círculo de Leitores, Lisboa.

Hawkins, P., \& Winter J. (1996). The self-reliant graduate and the SME. Education + Training, 38(4), 3-9.

Hoffmann, T. (1999). The meanings of competency. Journal of European Industrial training, 23(6), 275-285.

Ibáñez-Martín, J. A., Fuentes, J. L., \& Barrio, J. M. (2012). Competencias sociales e inmigración desde una perspectiva intercultural. Educación XX1, 15(2), 41-72.

Laughton D., \& Montanheiro, L. (1996). Core skills in higher education: the student perspective. Education + Training, 38(4), 17-24.

Laužackas, R., Tūtlys, V., \& Spūdyte, I. (2009). Evolution of competence concept in Lithuania: from VET reform to development of National Qualifications System. Journal of European Industrial Training, 33(8/9), 800-816.

Martins, A., Martins, I., \& Pereira, O. P. (2013). Organisational flexibility through human capital development. In Knowledge Management Innovations for Interdisciplinary Education: Organizational Applications, Edited by Buckley, S. and Jakovljevic, M., IGI Global, chapter 3: 51-61, DOI: 10.4018/9781-4666-1969-2.choo3.

Munthe, E., Malmo, K-A. S., \& Rogne, M. (2011). Teacher education reform and challenges in Norway. Journal of Education for Teaching, 37(4), 441-450. 
Pereira, O. P. (2013a). Soft Skills: From University to Work Environment. A Survey of Graduates In Portugal. Regional and Sectoral Economic Studies, 13(1), 105-118.

Pereira, O. P. (2013b). Metacompeteces: how important for organizations? Analysis of a survey in Portugal. Regional and Sectoral Economic Studies, 13(2), 73-88.

Pereira, O. P. (2015). VET: Strategic approach for economic, organizational and personal development in EU countries. Revista Galega de Economia, 24(2), 111-124.

Pereira O. P., \& Correia, I. M. (2007). Externalidades da Investigação Universitária Sobre a Produtividade Das Empresas Em Portugal. Regional and Sectorial Economic Studies, 7(2), 89-112.

Pereira, O. P., \& Coutinho, M. C. (2009). Knowledge Society and the Challenges to University Teaching: Application to Portugal. Estudios Económicos de Desarrollo Internacional/Economic Studies of International Development, 9(2), 109-126.

Pereira, O. P., \& Assoreira, M. J. (2012). Society and Technological Evolution: Challenges and Opportunities. Regional and Sectoral Economic Studies, 12(2), 51-67.

Roing Cotada, J., \& Villarreal Rodríguez E. (2008). Opinión de empleadores y titulados sobre las competencias. In Investigaciones de Economía de la Educación, edited by Neira et al (ed.). AEDEasociación de economía de la educación, número 3: 249-255, España.

Smidt, W. (2015). Big Five personality traits as predictors of the academic success of university and college students in early childhood education. Journal of Education for Teaching, 41(4), 385-403.

Stagg, P. (1996). Initial teacher training and business links: built-in, not bolt-on?. Education + Training, 38(4), $10-16$.

Tejada, J. (2012). La alternancia de contextos para la adquisición de competencias profesionales en escenarios complementarios de educación superior: marco y estratégia. Educación XX1, 15(2), 17-40.

Tejada, J., \& Ruiz, C. (2016). Evaluación de Competencias Profesionales en Educación Superior: Retos e Implicaciones. Educación XX1, 19(1), 17-38.

Thongthew, S. (2014). Changes in teacher education in Thailand 1978-2014. Journal of Education for Teaching, 40(5), 543-550.

Waterman, R., Waterman, J., \& Collard, B. A. (1994). Towards A Career Resilient Workforce. Harvard Business Review, July-August, 87-95.

Zhou, J. (2014). Teacher education changes in China: 1974-2014. Journal of Education for Teaching, 40(5), 507-523. 